\title{
The Tea Party Movement and the Geography of Collective Action
}

\author{
Wendy K. Tam Cho ${ }^{1}$, James G. Gimpel ${ }^{2}$ and Daron R. Shaw ${ }^{3}$ \\ ${ }^{1}$ University of Illinois at Urbana-Champaign,wendycho@illinois.edu \\ ${ }^{2}$ University of Maryland,jgimpel@gvpt.umd.edu \\ ${ }^{3}$ University of Texas-Austin, dshaw@austin.utexas.edu
}

\begin{abstract}
We examine the geography of the Tea Party movement by drawing upon a unique data source that harvested thousands of events from the Meetup.org and Tea Party Patriots websites during the latter half of 2010. The spatial distribution of events strongly suggests that Tea Party activism was borne out of economic grievance, as it corresponds quite closely to the incidence of home foreclosures. The findings more generally reinforce the impression that Tea Party activists varied in the extent of their broader political vision and strategic acumen. On the one hand, many gathered together to express dissent and make their opposition identity known wherever they happened to live. But some did unite with like-minded groups to direct their activity toward defeating incumbents, capturing open seats, and electing their own candidates, possibly altering the outcome in a number of elections, primary and general. A geographic perspective on movement activism reveals that while not remarkably strategic with respect to the 2010 elections, Tea Party protest was not purely expressive either.
\end{abstract}

Supplementary Material available from: http://dx.doi.org/10.1561/100.00011051_supp

MS submitted 17 June 2011; final version received 31 January 2012

ISSN 1554-0626; DOI 10.1561/100.00011051

(c) 2012 W. K. T. Cho, J. G. Gimpel and D. R. Shaw 
Since the proliferation of Tea Party protests at the beginning of the 2010 election cycle, journalists, pundits, and scholars have debated both the origins and prospects for the movement. More recently, experts have focused their attention on the longevity and continuity of the Tea Party, which has surpassed that of most grassroots movements. Most grassroots movements lack a central organizing force and melt away quickly. The Tea Party movement, however, remained a vibrant force throughout 2010 and into 2012, confounding many political observers who had predicted its dissolution. Are levels of frustration with the government so high that they motivate and sustain membership in these organizations? How will candidates sympathetic to (or formally aligned with) the Tea Party fare in elections? Will the Tea Party movement leave a lasting imprint on American politics?

For many, the Tea Party offers an intriguing window on the larger question of political movements in the United States. Rational choice perspectives on politics suggest that the mobilization of mass publics around a political principle is exceptional and requires substantial effort by political elites, who need to be motivated by selective benefits to bear the costs of organizing (see, for example, Aldrich, 1996). This perspective was embraced (perhaps ironically) by liberal and progressive pundits, who argued that the Tea Party was the creation of conservative elites. Others contend that the American two-party system has effectively limited representation of alternative viewpoints and that this has created a genuine mass movement built around anti-establishment sentiment (Hinich and Shaw, 2009). Collective action problems have been surmounted by intense and emotional programmatic concerns, along with the solidary benefits associated with voicing common grievances.

We examine the Tea Party movement with the hope of learning more about how social movements can overcome collective action issues. More specifically, we gather event data from Meetup.org and the Tea Party Patriots and systematically analyze the geographic patterns of Tea Party activities throughout 2010. Our purpose is largely exploratory — we map the data and empirically test a series of associative relationships. These associations, to the extent they prove powerful, suggest explanations for the movement's occurrence. In this sense, we seek to surmise theoretical relationships based on empirical patterns. Perhaps more to the point, we seek to substitute hard evidence for the often polemical argumentation that so often defines routine discussions of the Tea Party movement. 


\section{Origins of the Movement}

The genesis of the Tea Party protest movement is widely believed to have originated from the floor of the Chicago Mercantile Exchange with Business news editor Rick Santelli's February 19, 2009, early morning CNBC on-air rant about the Obama Administration's proposed mortgage bailout program. Santelli complained bitterly that such assistance was rewarding "losers" at the expense of people who had played by the rules. Amidst cheering traders, he invited "all you capitalists" to a "Chicago Tea Party" on the shores of Lake Michigan to protest big government having gone too far. Within days, a video of his tirade went viral, and a movement was borne or so the media lore goes (Zernike, 2010).

By at least one authoritative account, however, the first Tea Party-like protest had occurred three days earlier, in Seattle, Washington, organized by a single activist to protest the economic stimulus package. The event was attended by approximately 100 people, and garnered at least token support from conservative activists (Zernike, 2010). Moreover, the seeds were surely planted with the discontent on the right arising from the recession that began late in the Bush Administration in 2008 (Hirsh, 2010). Santelli, however, certainly drew attention to the growing anxiety about government spending among business-minded Republicans and libertarians, and he linked this angst historically to the well-recognized Revolutionary War-era protests (McGrath, 2010; Zernike, 2010).

Once the video of Santelli's tirade hit YouTube, weeks of airplay and sympathetic reactions on Fox News programs and conservative talk radio followed. Legions of Ron Paul's energetic supporters, sharing Santelli's freemarket views, were among the first to enlist. Their already impressive online presence helped spread the movement from coast-to-coast, fueling significant Republican wins in the November 2009 New Jersey and Virginia gubernatorial elections (Kirby and Boaz, 2010). A more developed (if separate) philosophy was also promulgated and advanced by conservative Republicans through a steady drumbeat of appeals by former Fox News host Glenn Beck, and former Alaska-governor-turned-conservative-activist Sarah Palin.

\section{Geographic Imprints of Tea Party Activity}

As the movement blazed on with a fierceness that only the Internet could fuel, the barrage of Tea Party activity became too complex to categorize 
neatly. Which events sparked what events became anyone's guess. The true origins of a movement that seemed to have been spurred by a spontaneous outpouring of public discontent were questioned. In a New York Times opinion column in April 2009, Paul Krugman claimed that the organization was "astroturfed" (that is, it was not a true grassroots movement). Similarly, Speaker of the House Nancy Pelosi chimed in, "[i]t's not really a grassroots movement. It's astroturf by some of the wealthiest people in America to keep the focus on tax cuts for the rich instead of for the great middle class."

In many ways, the vigorous debate about whether the Tea Party meetings are organic, popular, grass-roots expressions or elite-driven, narrow, "astroturf" fabrications can be dismissed as a highly partisan blog war. Like most political movements, left and right, it has both a national presence with professional organizers monitoring developments from central offices, and a grassroots component that is spontaneous and locally cultivated (Minkoff, 1997; Lo, 1982, p. 113). Participants may be simply expressing their frustration with current political and economic conditions while there may also be upper echelon coordination to elect candidates who are aligned with Tea Party values. Because politics is so interlaced with geography, one way to gain insight into the Tea Party is to examine the geographic loci of movement activity. Is the activity concentrated in locations where middle-class economic grievances arose to a boiling point or in areas where strategic elites stoked these protest fires in hopes of defeating incumbent members of Congress?

\section{Geographic Patterns of Strategically Coordinated Activity}

We know that political campaigns are supremely strategic in how they plan and schedule events, leaving very little to chance (Shaw, 1999, 2006; Holbrook and McClurg, 2005; Chen and Reeves, 2011). Events are meticulously scheduled according to a state or election district's potential for victory, judged mainly on the basis of its past voting history and contemporary polling numbers (Shaw, 2006, p. 55). Had the Tea Party movement been subject to the guidance of national Republican leadership and control, then there would have been clear implications for event scheduling, as the lion's share of campaign resources would have been channeled toward battleground congressional districts, and hotly contested senate seats. Guided by such overarching criteria, the preponderance of Tea Party events would appear 
in those congressional districts where there was a clear instrumental and strategic calculation that political offices could have been gained by dent of organized activity.

There are, of course, other elites who might have embraced other, perhaps rival, strategic goals. Setting aside Republican Party leadership, ideological elites might have targeted incumbents on the basis of membership on big-spending committees in Congress. Recall that the Tea Party supported candidates in 2010 aggressively campaigned on earmark bans and congressional spending reform. Given that government spending and debt were major issues for the Tea Party rank-and-file and candidates alike, one might therefore expect Tea Party activity to be of heightened intensity in states and districts represented by appropriators of either party (e.g., Lisa Murkowski (R-AK) and Robert Bennett (R-UT), among Republicans, and Patty Murray (D-WA) and Chet Edwards (D-TX), among Democrats). Murray and Murkowski ultimately won re-election while Edwards and Bennett were defeated, the latter in the GOP primary. Other appropriators who ultimately lost a hotly contested race included Alan Mollohan (D-WV) who was defeated in a primary challenge and a number of less senior House Democrats, including Allen Boyd (D-FL), John Salazar (D-FL), Ciro Rodriguez (D-TX), and Lincoln Davis (D-TN). ${ }^{1}$ In addition, Republicans gained two seats where Democratic appropriators retired (David Obey (D-WI) and Marion Berry (D-AR)).

Again, note the nomination contest success of Tea Party candidates at the expense of moderate, but broadly popular Republicans. In particular, the GOP primary victories of Christine O'Donnell over Mike Castle in Delaware, Rand Paul over Trey Grayson in Kentucky, Joe Miller over Lisa Murkowski in Alaska, Marco Rubio over Charlie Crist in Florida, and Sharon Angle over Sue Lowden in Nevada, were cited as evidence that the Tea Party would severely limit the magnitude of the Republican gains in the midterm elections, especially in the U.S. Senate. More importantly, for our purposes, these primary election challenges can be viewed as strategic activity, albeit not driven by the Republican Party. This was surely the thinking of Republican strategist Karl Rove, who referred to the Tea Party movement as "naïve."

1 House appropriations member Joseph Cao (R-LA) was also defeated in the general election, though his loss could not be attributed to Tea Party opposition. 


\section{Geographic Patterns of Expressive Activity}

On the other hand, when we examine the geographic patterns of Tea Party activity, we may find that Tea Party events do not closely align with obvious, near-term, strategic agendas but are, instead, more haphazardly located, perhaps simply arising near where the grassroots supporters reside. It is possible, of course, that these patterns could coincide with very different strategic imperatives. Movement leaders may be engaged in long-term organization building in specific locations, cultivating news media in certain areas, or looking to build volunteer or fundraising bases. But let us assume that such a geographic dispersion of events is perhaps even suggestive of ideological, programmatic, or expressive motives (Brennan and Buchanan, 1984; Brennan and Lomasky, 1985; Schuessler, 2000, pp. 87--88). Tea party participants, from this point of view, participate and demonstrate not necessarily to achieve a particular political end, but to identify themselves with the movement. Taken to its extreme, the idea is that the individual is gratified by revealing a pungent political preference, regardless of whether his preferred congressional candidate wins (Brennan and Lomasky, 1993; Engelen, 2006). If political events were expressive in this way, then their geographic location in 2010 would not necessarily coincide with the whereabouts of vulnerable incumbent officeholders or competitive open seat contests.

Politically expressive activity may also manifest itself as activity near areas of economic downturn. This would seem natural since the core issues for the Tea Party are economic in nature (Williamson et al., 2011, p. 31). Some are clearly expressing identity — that they are Republicans who identify with the small government, anti-debt, anti-regulatory message of the Tea Party. Others are objecting to the present administration's policies - mostly the spending and economic stimulus plans - akin to the protests from 2005 to 2008 that expressed opposition to the Bush Administration's Iraq War policy. Still others are voicing disapproval of the sustained economic problems that began under the previous administration, but continued well beyond 2010. These complaints are not only about the policies of the present administration and their failure to improve conditions, but also about the dire economic conditions themselves. The specific economic problems may vary from place to place, as this recession rose from multifaceted sources, resulting in high foreclosure rates in some locations, unemployment in others, and the evaporation of investment portfolios and home equity in still others. 


\section{Expectations and Hypotheses}

It is our conviction that the Tea Party movement was simultaneously expressive and strategic, where strategic is defined from a short-term political perspective, with a particular focus on electoral success in 2010. We would be surprised if Tea Party events and activities were not concentrated in geographic areas where economic indicators were particularly dismal, but we would be equally surprised if Tea Party activities were randomly distributed with respect to incumbent vulnerability. Nonetheless, while evidence may be present for both scenarios, strategic patterns may be difficult to discern since the most prominent Tea Party candidates came from both competitive and non-competitive states and districts. ${ }^{2}$ In addition, there is widely reported tension among Tea Party activists, their candidates, and the Republican Party establishment - a rivalry that, at least in the short term, would surely stand in the way of obvious strategic coordination. Another reason for this expectation is deductive. In order to generate a movement like the Tea Party, powerfully emotional grievances must be articulated, which, once set into motion, can be strategically channeled only with great planning and skill. This observation fits with an admittedly anecdotal recollection of the election: Tea Party supporters were likely to oppose Democratic incumbents in the general election, but they were only slightly less likely to oppose ideologically moderate Republicans in primary elections. Getting them to support moderate, but presumably electable Republicans in primaries and to only target specific, vulnerable Democrats in the general election strikes us as a herculean task. While the analysis here is tentative, we expect emotion to rival obvious electorally strategic considerations.

In more particular terms, our main expectation is that Tea Party activism in 2010 is best explained by two factors: (1) the depth and intensity of economic hardship in the area, and (2) the number of people holding sympathetic policy views in the area. If Tea Party activism is driven by a sense that the government is out of touch and is not responding effectively to the problems at hand, then this sentiment is most likely to be felt where objective indicators attest to this underlying opinion. The places where foreclosure rates and unemployment are especially high are where we might witness strong Tea Party activism anchored in economic grievance. Foreclosures

2 The Senate races cited above came from Alaska, Nevada, Kentucky, Delaware, and Florida. 
may be a greater catalyst for Tea Party activity than unemployment rates, simply because they are a newer crisis phenomenon, hitting middle class and Republican areas especially hard. Unemployment, on the other hand, is often a longstanding feature of blight in the areas where it is traditionally high. It may not fuel much protest if conservative and Republican populations remain relatively unaffected or if the general population becomes inured to economic hardship following extended periods of joblessness (Ebeid and Rodden, 2006; Schlozman and Verba, 1979). The second of these factors the underlying policy predispositions of residents in a location — would manifest itself as high Tea Party activism rates where there are relatively high proportions of Republicans (and especially fiscally conservative Republicans). GOP partisans were highly predisposed to think that the federal government mismanaged the 2008-2009 economic crisis and over-stepped its constitutional limits.

Returning to the broad themes touched on earlier, the occurrence of Tea Party activities in competitive districts and states would be consistent with rational choice expectations that the movement has been directed by elites seeking to obtain selective benefits associated with winning office and gaining power in the corridors of Washington. Surely, less obvious strategic patterns do not necessarily indicate that the selective benefits explanation is wrong, but would merely point to more subtle strategic considerations, which may be bound up in the explicit representation of anti-government ideology and political outrage. In other words, if Tea Party activities are not concentrated in electorally competitive districts and states, it may be that they are purely expressive or it may be that group leaders think there is greater value in organizing activities where strength and clout can be plainly demonstrated. In either case, the main story is not an elite-driven effort to recapture a majority in the Congress.

\section{The Events Data}

We explore the relationship between the thousands of pre- and post-primary Tea Party events (from June to Election Day, 2010), the competitiveness of U.S. House and Senate seats in voter rich areas, and measures of worsening economic conditions in the form of home foreclosures and rising unemployment. Our data on Tea Party events was culled from the www.meetup.org website and the event schedule for the Tea Party Patriots, the largest 
grassroots group. These meetings ranged in size and purpose, from a handful of activists gathering together to discuss ideas and plan future activities, to larger protest events, often involving several hundred people. ${ }^{3}$ In all, we located 5990 meetings precisely to the street level; 4211 of these, or about 70 percent of the total, occurred in the post-primary period. The remaining 1779 occurred before.

\section{Distribution of Events: June-November}

A map displaying the locations of meeting sites appears in Figure 1. ${ }^{4}$ Meetup.org listings also identify the size of the local membership of the organization convening the event, although that does not necessarily reflect the size of the gathering. At the low end, about 70 of the Meetup.org meetings $(3.6 \%)$ identified the local sponsoring organization as having five or fewer members. At the high end, 380 meetings (7.2\%) identified the local sponsor as having over 1000 members. The largest local membership groups in the data, both with reportedly over 1500 members by late in the year, were based in Tampa, Florida, and Raleigh, North Carolina. In total, over 600 separate groups scheduled events using Meetup.org, reporting an average local membership size of about 119, and a grand total of 76,000 members - though an unknown number of members may belong to multiple groups. On average, events were sponsored by groups with 240 members, indicating that the larger groups scheduled more events. Nothing in the data provided an indication of meeting attendance, only the membership size of the sponsoring local organization.

Figure 2 illustrates the geographic distribution, or centrography, of the political events shown in Figure 1, as well as the pre-primary and postprimary distributions. The ellipses encompass a single standard deviation of

3 The Meetup.org data did have to be closely scrutinized, as some "Tea Party" listings were not actual political meetings of Tea Party affiliated political groups. We eliminated non-Tea Party meetings and removed duplicate events that appeared on both lists. Because of the informal and slapdash nature of many local groups, we were not able to determine precisely what percentage of total nationwide Tea Party events were listed on www.meetup.org and the Tea Party Patriots sites, though we are more certain that it captured the bulk of the events scheduled by the larger Tea Party groups, and the organizations in urban and suburban areas.

4 Our data capture the periodic meetings of local Tea Party Patriots chapters, as well as Glenn Beck's related 9-12 Project groups, scattered around the country. Numerous other organizations and chapters of groups with names such as The Children of Liberty, the Defenders of Liberty, the Articles of Freedom, the Sons of the Republic, the Constitutional Patriots, the Freedom Network, America's Independent Party Caucus, and the Citizen's Awareness Network, are identified on the site. 


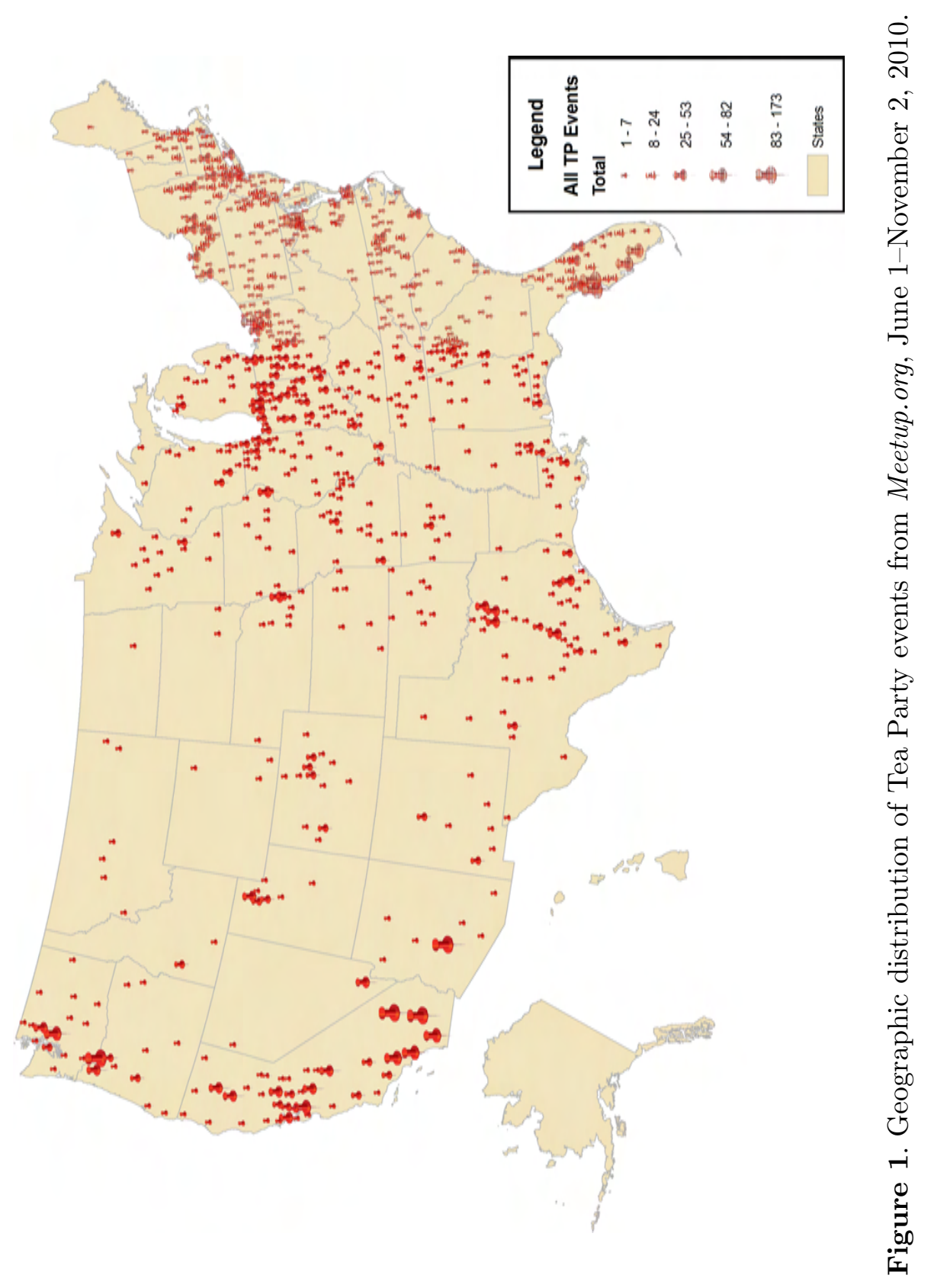




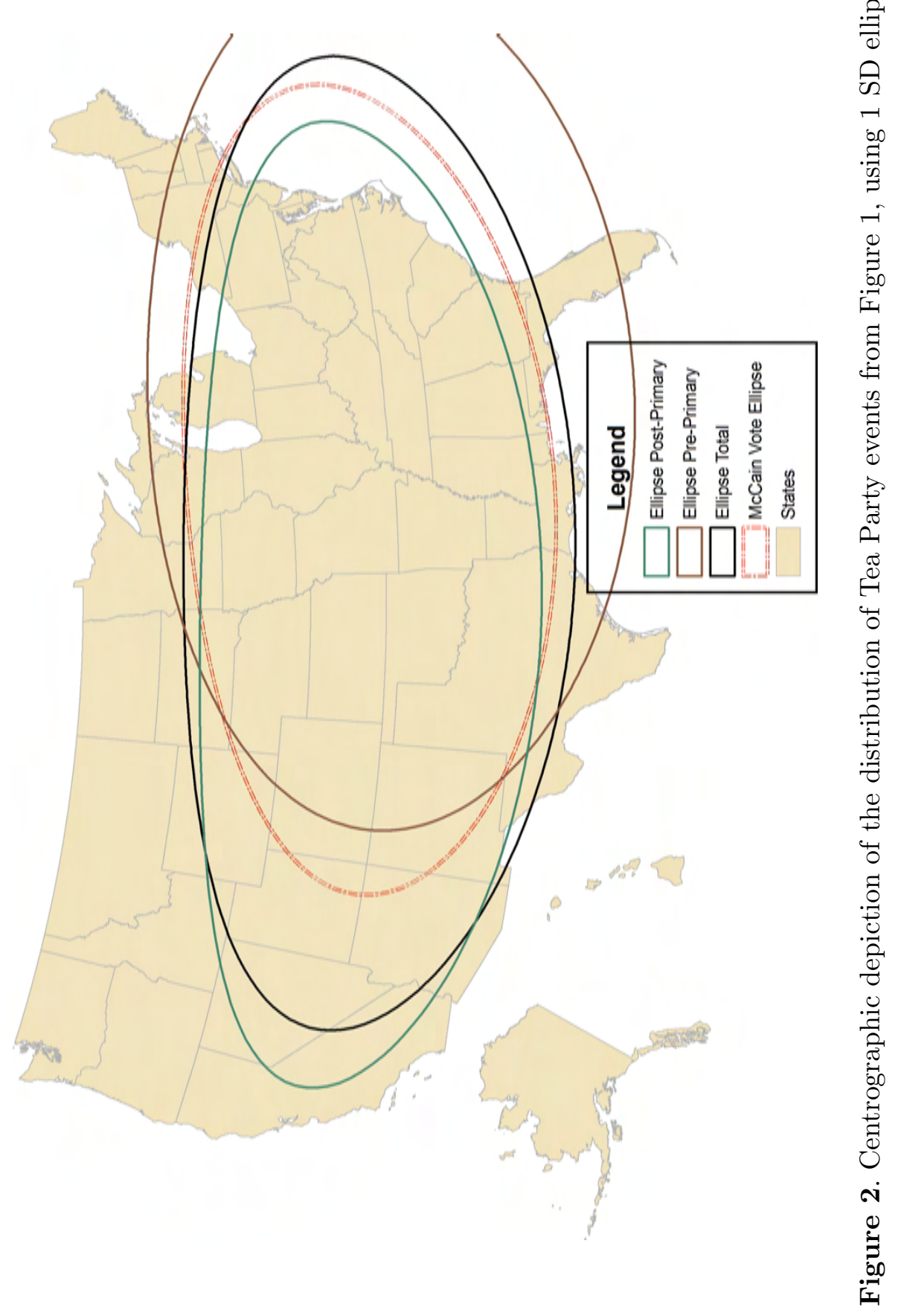


distance from the mean center of the distributions. For reference purposes, we have included the ellipse depicting the geographic distribution of the McCain vote in 2008. Compared to McCain's pattern of electoral support, the national distribution of Tea Party activism is considerably more western, both for total events (black line) and especially for those occurring after the primary (green line). Prior to state primaries, however, the distribution of activity is actually more eastern. The shift from east to west reflects the influence of the large number of events in Nevada, Arizona and California later in the campaign season.

Figures 3 (pre-primary) and 4 (general election) display significant hot spots of Tea Party activity. These maps display the Getis-Ord $G_{i}^{*}$ statistic. High values of $G_{i}^{*}$ (indicated by darker shades of red) correspond to intense or hot spots of Tea Party activity. In Figure 3, we see that the initial foci of Tea Party activism were in four specific locations: the Southwest, the Seattle metro area, lower New England, and the Florida peninsula. From early to late in campaign season, however, the centers of movement activism spread to cover the rest of California and the most populous parts of Arizona, Southwest Washington and the greater Portland area, the Dallas-Fort Worth Metroplex, Central North Carolina, and the Upper Midwest. Populous counties in Nevada and Utah also appear as late-developing Tea Party hot spots. Activism appears to be highly localized, and not as extensive as many have come to believe.

\section{A Look at Mass Support in Early 2010}

National opinion polls allow another glimpse of Tea Party support and provide a different perspective to complement the geographic patterns. Pew Center surveys (in March, May, and June) displayed high party polarization: $82 \%$ of those expressing sympathy with the Tea Party were Republicans or Republican leaners while $85 \%$ of those expressing any disagreement were Democrats. Table 1 reports the percentages by location and region of Republicans, Democrats, party leaners and Independents, who agreed or strongly agreed with the Tea Party movement. While Republican support is fairly uniform throughout the country, the robust support among those who call themselves Republican leaners is noteworthy. Apparently, these weak parti-

sans were most enthusiastic in the West. In that region, fully 33 percent of all Tea Party supporters were leaning or weak partisans (Table 1). Moreover, 


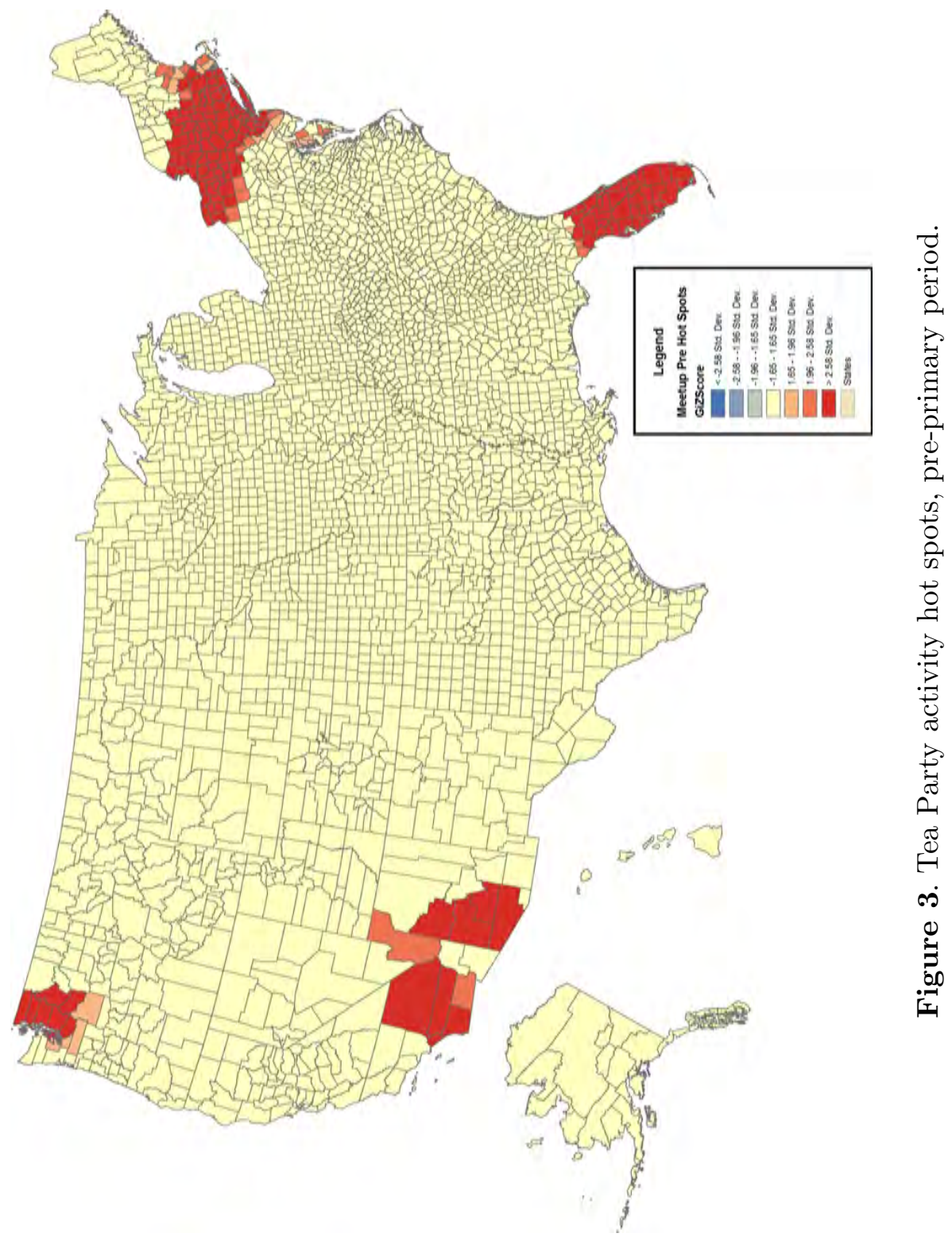




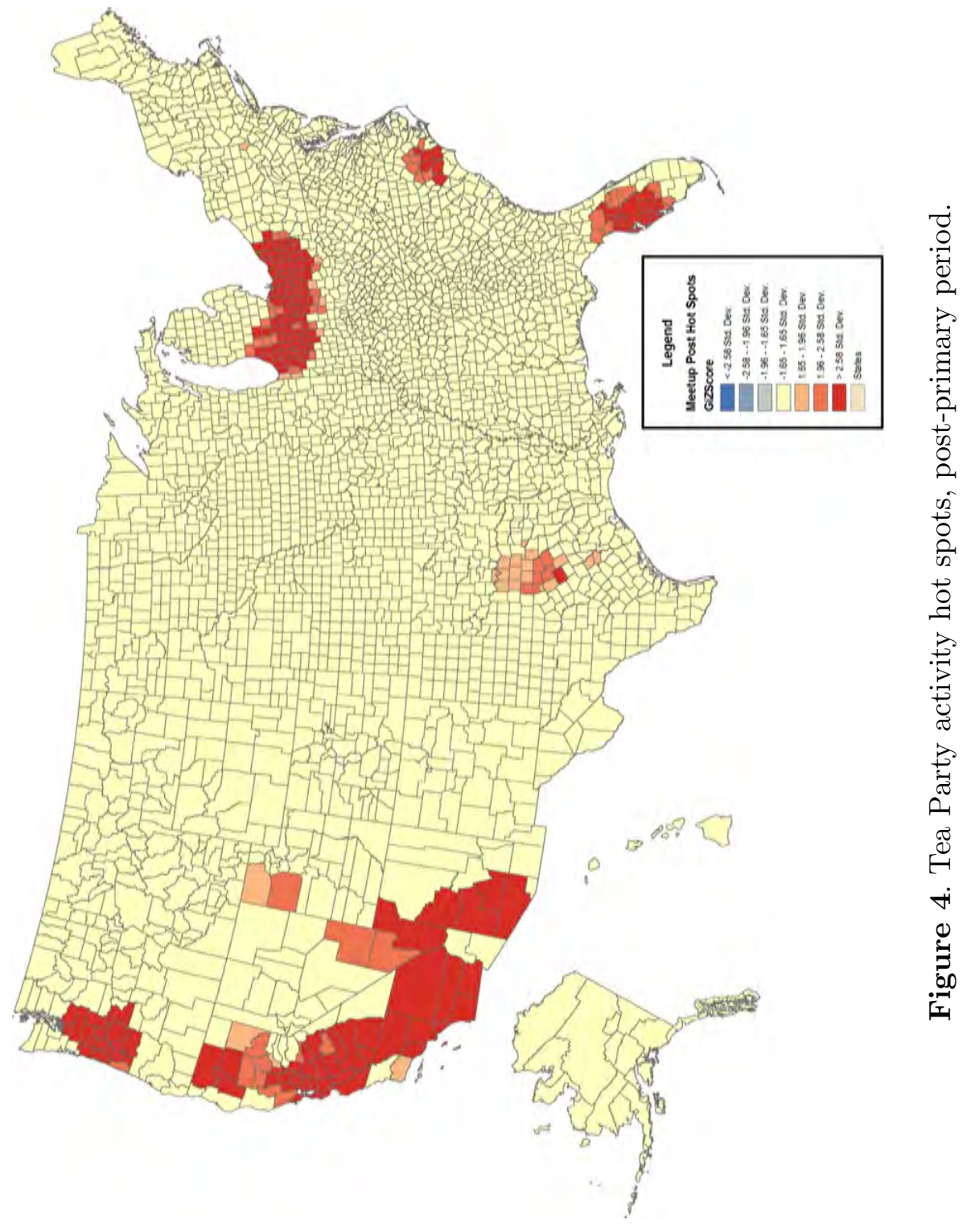




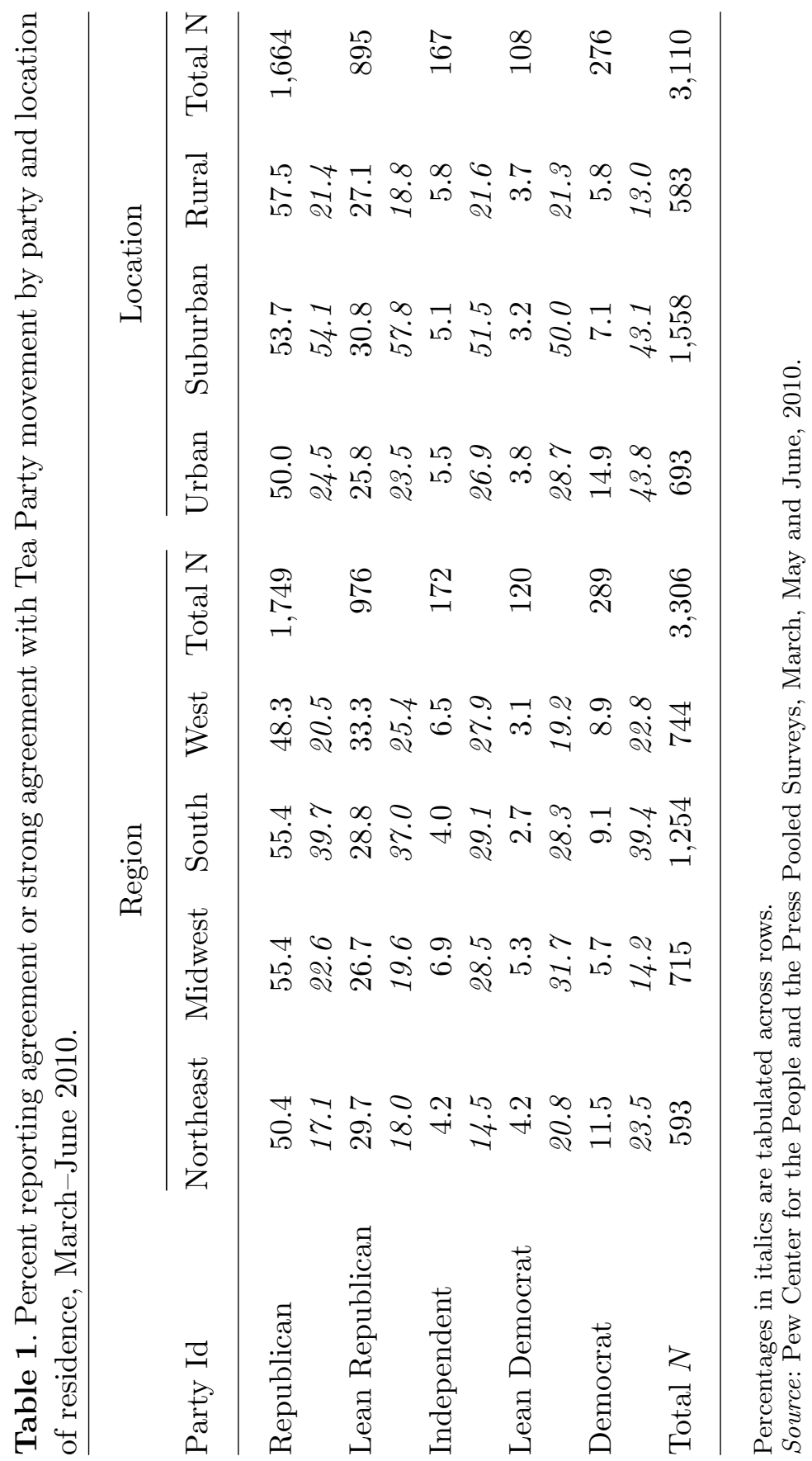


expressed as a percentage, the support of Western Republican leaners for the Tea Party exceeds that of regular party identifiers in these surveys (seen by tabulating the cell percentages across the rows in Table 1).

Also of note is the fact that the percentage of leaning Republicans in suburban areas drawn to the movement is especially significant from the early months of the election year (see Table 1). These figures confirm the widely held perception that it was unorthodox Republicans - those identified with Ron Paul and others on the fringe of mainstream GOP politics - who were attracted to the movement, while committed Republicans were slightly slower to fully engage, at least in the early months. Finally, the Tea Party had built considerable popular support by early 2010 not just in rural areas and small towns, where small government and anti-government themes always play well, but in populous urban and suburban areas. In summary, the Pew surveys suggest that the balance of early support for the movement was embedded in the suburbs among older white non-Latino citizens with modest levels of education and middle but not high incomes.

The picture of mass support for the Tea Party suggests libertarian and small government activists in the party drew Republican regulars into the fray. Eventually, the movement would garner the support of party stalwarts, along with about one-fourth of the Independents, many of whom may have been irregular voters in previous elections. The opinion surveys early in 2010 indicate that the geography of Tea Party support and membership is closely associated with the electoral geography of the Republican Party, suggesting that Tea Party events arise out of GOP activism.

\section{Geographic Models of Tea Party Activity}

It is clear from the earlier maps that the geographic distribution of events is not uniform, but instead, exhibits definite clustering. The mechanisms that create these patterns are less clear. Some of these impetuses are geographic in nature, perhaps a contagion-type effect where movement enlistment proliferates. Other reasons for these patterns may be attributable to non-geographic components such as income or previous presidential support. If so,the geographic distribution of events could be partially or wholly accounted for by a model that controls for income and previous vote preference. The mechanism creating the geographic structure would not then be a spatial process per se, but rather connected to income or partisanship. Regardless of whether 
events arise as part of an explicit spatial process, or simply as an artifact of underlying population characteristics, spatial analyses are important for both substantive as well as statistical reasons. ${ }^{5}$ On the substantive front, spatial models allow us to examine critically theories about the political behavior of individuals in context. Statistically, if spatial processes underlie the behavior of interest but are not accounted for in the model, inferences will be inaccurate and coefficient estimates may be biased. Erroneously ignoring spatial dependence may create bias and inconsistency in the same way that we understand the omitted variable problem to affect OLS estimates (Anselin, 1988, 1990). Alternatively, if the spatial structure is contained in unmeasured covariates, the estimates are inefficient because the standard errors are biased (Anselin and Griffith, 1988).

Gaining insight into these patterns is the heart of this study and the task to which we now turn. The dependent variable in our spatial analysis is the natural $\log$ of the Tea Party event count from June 1 to November 2, 2011. ${ }^{6}$ We estimate a spatial lag model for both the pre-primary and post-primary periods. ${ }^{7}$ The spatial lag model is

$$
y=\rho W y+\mathrm{X} \beta+\epsilon
$$

where $W$ is an $N \times N$ spatial weights matrix, $\rho$ is the spatial autoregressive coefficient, $\epsilon$ is the error term, and $X$ and $\beta$ have the usual interpretation in an OLS regression model. ${ }^{8}$ The spatial lag can be seen as a weighted average

5 When we refer to spatial models, we are making specific reference to statistical models that incorporate information about the location of the observation. These would include the spatial autoregressive models such as the spatial lag and spatial error models. We are not referring to Downsian spatial models of party competition or models that incorporate space in a sense that is not directly related to geography.

6 We define neighbors with a queen contiguity criterion, assigning two spatial units as contiguous if they share a common border. The most active Tea Party members will often attend events in more than just a single jurisdiction, and organizations may recruit members from several neighboring jurisdictions. Events in one jurisdiction may also spillover to influence the scheduling of events in neighboring jurisdictions. Higher order contiguity matrices in which more distant neighbors are considered linked, were also considered, but ultimately found to be unnecessary to correct the least squares estimates.

7 Although a monthly panel design might seem more desirable, so as to incorporate the time dimension of variability, when using the 3141 counties as observations on an $N$ of only 5300 events, such a design leads to very sparse counts, and highly inflated 0 counts for the vast majority of observations. In addition, separate pre-primary and post-primary cross-sections were desirable since primary and general elections commonly involve differing strategic calculations.

8 The spatial lag model was chosen instead of the spatial error model because the LaGrange Multiplier diagnostics favored the lag model. 
of its geographically-defined neighbors. In this model specification, because the lag term is correlated with the error term, OLS should not be used, since it will be both biased and inconsistent (Ord, 1975; Anselin, 1988).

Apart from the spatial lag term, other components of the model capture factors that may help identify attributes associated with Tea Party activism. Our models include variables that gauge election competition and local economic conditions. We also examine attributes of populations such as variability in occupation as a measure of economic interest. To account for temporal variability in events, we control for key dates on the political calendar. Lastly, we sought to distinguish activism that may have been stirred by other, less grassroots-oriented national and regional Tea Party organizations through their financial contributions to candidates. ${ }^{9}$

\section{Results of Estimation}

Results from our spatial lag model for the logged number of events by congressional district and county from the Meetup.org and Tea Party Patriots schedules for the pre-primary period of the 2010 election are presented in Table 2. For each period, we present two models. The second specification includes elements that are more electorally strategic in nature.

First, a large number of events were scheduled in areas that would be most inclined to protest economic conditions. The second model (at the congressional district level) suggests that for every standard deviation increase in the foreclosure rate (per 1000 households) $(\sigma=21.1)$ there was an average increase of 21.2 additional Tea Party events. Protest was heightened in areas of economic hardship, but principally where that hardship came in the form of home foreclosures. On the other hand, locations of high unemployment were not always Tea Party hotbeds. The relevant coefficient is actually negative and of mixed statistical significance across congressional districts and is negative and significant across counties.

These are aggregated units, so the significant coefficient does not mean, of course, that those who lost their homes were themselves the ones who were protesting, nor does it indicate that the unemployed did not protest. Instead,

9 These include Freedomworks, the Tea Party Express, and Liberty First. To evaluate the linkage between campaign giving by Tea Party related PACs, and the count of Tea Party events locally, we distinguish PAC donations by when they were given; during the primary, or during the general election period. 


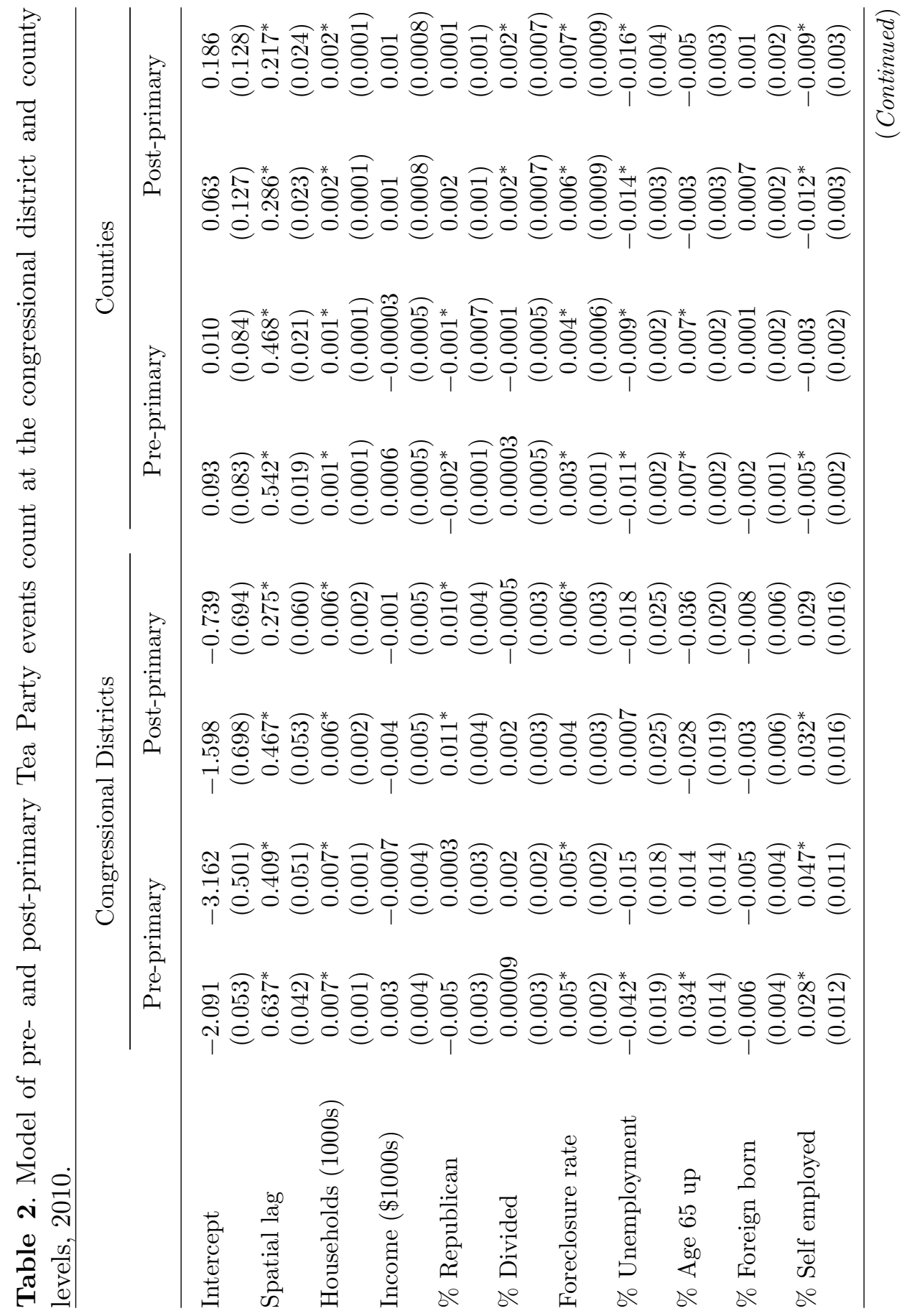




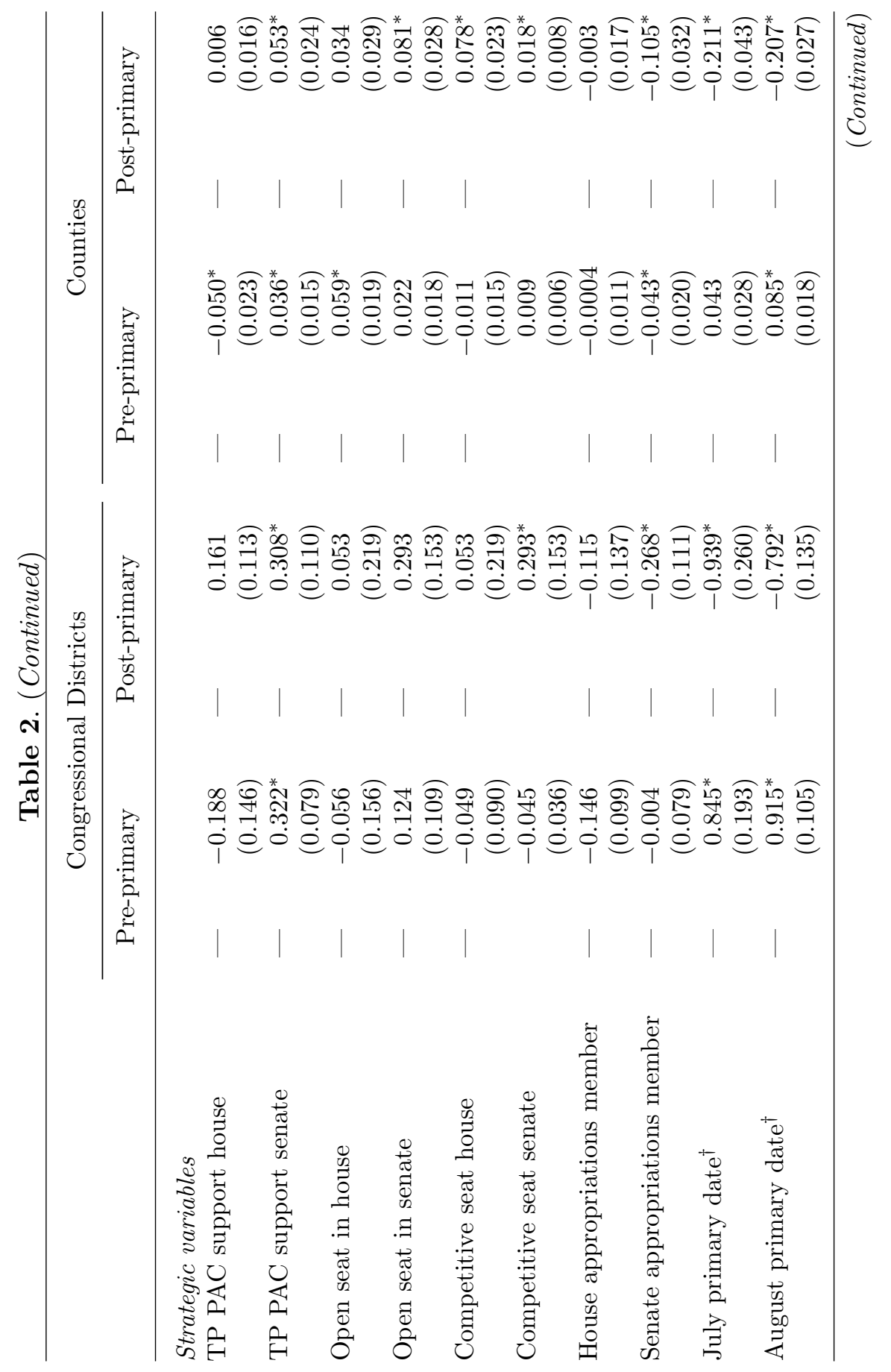




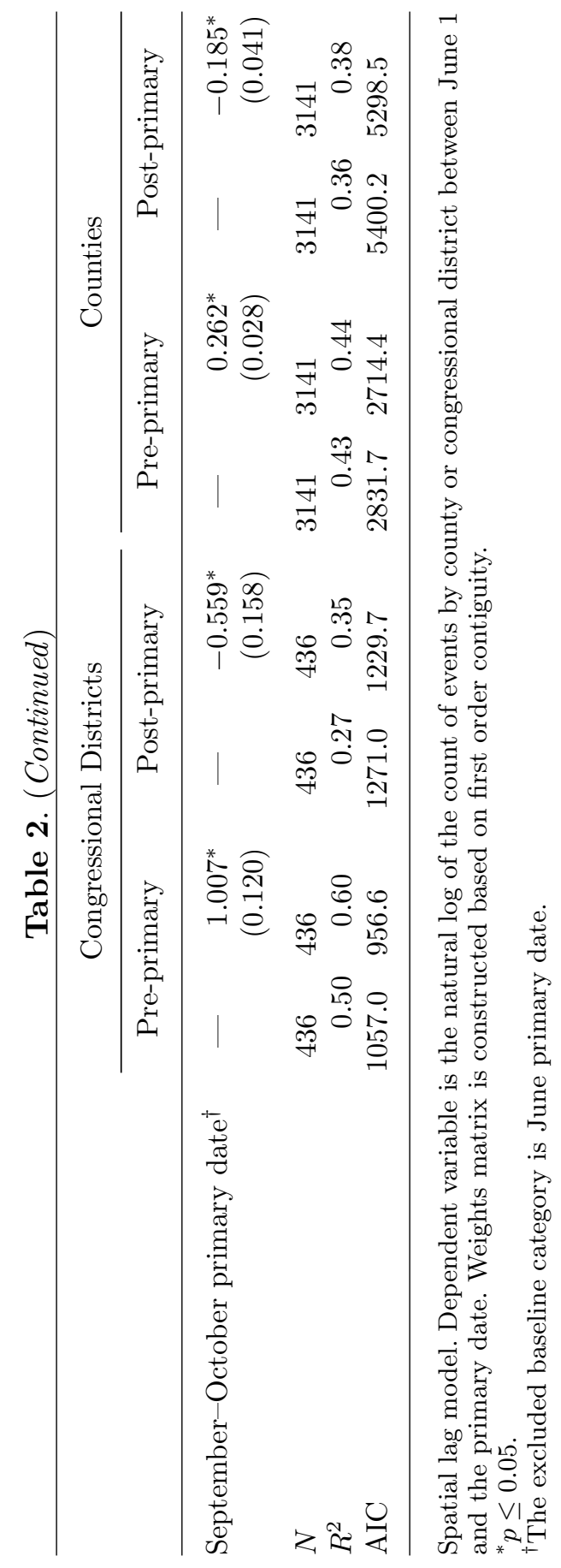


it may well have been those who were upset about foreclosures that were doing the protesting — following Rick Santelli's lead. The protestors may very well have been among the many whose home and related investment equity had vanished in areas with badly depressed housing markets. Whatever the case, we observe remarkably higher Tea Party activity in "housingbubble" states such as Nevada, Florida, Arizona, and California, all with very high foreclosure rates beginning back in 2008. Of the top 50 counties with the highest unemployment rates in the months leading up to June 2010, only seven saw any Tea Party events between June and November, with Merced, California, leading the way with 30 events. But the top 50 counties in foreclosure rates played host to over 910 Tea Party events, about one-sixth of the total, with Phoenix, Arizona; Riverside, California; and San Bernardino, California, in the lead with a combined 454 events.

Notably, locations where the Republican percentage of the vote in presidential elections was particularly high from 2000 to 2008 were not appreciably more active in the pre-primary period at either the congressional district or county level once we control for other local conditions. If anything, the most Republican districts saw less activism, as shown in the county results, likely because many of these stalwart GOP locations are sparsely populated, and while they certainly sympathize with Tea Party ideology (see Table 1), they lack many of the resources essential for promoting organizational activism or protest.

Self-employment bears a statistically significant relationship to the number of events at the congressional district level, increasing the event count by 4.2 for every standard deviation increase in the percent self-employed $(\sigma=4)$. This effect remains in the congressional district data even after controlling for population size, which has a consistently positive impact on events. At the county level, however, the effect of self-employment is negative or not statistically significant, which would appear to falsify the notion that Tea Party protest was mainly a rural and small town phenomenon. In fact, events appeared in their most impressive numbers in suburbs, mid-sized, and larger cities where they stood to make a greater impression. Public protests, after all, require visible venues or noticeable spaces - a resource not in abundance in remote corners. The difference between the county and congressional district results for self-employment amplifies the point. While counties with high levels of self-employment held fewer events, congressional districts with high levels of self-employment held more. This is 
because protests did not always take place in the counties where particular residents resided, but in nearby larger counties, still within the same congressional district, where Tea Party protestors would converge to stage larger events and generate greater media coverage. Over the course of the entire period from June to November, the 100 largest counties, home to 40 percent of the nation's households, were the setting of about 45 percent of all of the scheduled activity over the entire period. At the other end of the population distribution, however, the 500 smallest counties, containing just over 1 million households, or 0.8 percent, programmed only 13 events, or 0.2 percent.

The various resources that advance the organization of any kind of social movement are not randomly or uniformly distributed. As a consequence, perhaps the single best predictor of events at one location is the presence of events at nearby locations. The estimated effect for the spatial lag is positive and highly statistically significant in every model. Another relevant indicator is age. Table 2 indicates that a single standard deviation $(\sigma=3.9)$ in the percentage of residents over age 65, generated an average of about four additional events per county prior to the primary elections, and perhaps 2-3 additional events per congressional district early on. Consistent with strategic behavior, the number of pre-primary events is significantly higher in critical areas. Wherever a U.S. Senate candidate had received support from a Tea Party group in the primary, the state's congressional districts observed an increase in Tea Party activism of about 1.5 percent.

Open Senate races saw greater Tea Party activity at the district and county level late in the campaign, but not in the pre-primary period. Open House seats saw more events only at the county level early in the campaign, but not late, and not across congressional districts. Senate seats receiving a "vulnerable" rating from The Cook Political Report saw more events in the general election period at both the county and congressional district level. But this analysis fails to detect much in the way of early strategic targeting by Tea Party organizations of House and Senate appropriators (of either party). Senate incumbents running for re-election are exposed to significantly fewer events in their states, on average, if they serve on the appropriations committee. Finally, the measures for the primary dates show that compared with the June baseline, July, August, and September each saw significantly more pre-primary events as the election year wore on and Tea Party groups gained membership and momentum. 
In summary, population size and location, along with high local foreclosure rates, appear to be the main stimuli for Tea Party events, both at the county and congressional district level. Probably the most notable difference between the pre- and post-primary models is the increased importance and impact of electorally strategic targeting later in the year. Between early and late in the election cycle, more events emerge in locations with open Senate seats. Because of their finer granularity, the county data are more decisive than the congressional district data on the greater role of strategic targeting late in the campaign. This is because events are carried out only in specific places within districts, and do not occur evenly throughout an entire district. During the general election period, we see more Tea Party assemblies in areas where there are open House and Senate seats, and for Senate seats in which Tea Party PACs have been involved (see Table 2). Consistent with strategic action, events also increase late in politically divided (i.e., purple) counties by late in the year, a phenomenon not evident either in the early months or at the congressional district level of observation.

\section{Examining and Mapping Residuals}

From the evidence presented so far, electorally strategic forces were only a minor part of the explanation for Tea Party events. Nevertheless, given the differences just described between early and later activities, we do want to offer some indication of where strategic factors may have played a role as Election Day drew near. To do this, we compared the absolute values of the residuals from the final model for the post-primary county data in Table 2 to those of the same model stripped of the strategic variables. We map the difference in the two residual values in Figure 5, with larger values (darker shades) indicating areas where strategic factors were more closely associated with Tea Party events.

The mapping of the reduction in residuals indicates that strategic factors explain Tea Party events in many locations, including much of the Upper Midwest, running from Minnesota and Wisconsin eastward in a belt toward Pennsylvania and New York. In a number of these areas, darkly shaded in the map, Republicans gained seats. ${ }^{10}$ While Tea Party activity may not be the cause of these GOP seat gains, activism in these cases is consistent with

10 These districts include MN-8, WI-8, IL-8, IL-11, IL-14; IN-8, IN-9, MI-1, OH-6, OH-15, OH-16, OH-18, PA-7, PA-8, PA-10, PA-11, NY-19, NY-24, and NY-25, as well as a scattering of seats outside this region, such as GA-8, LA-3, AR-2, AZ-1, NV-3 and WA-3. 


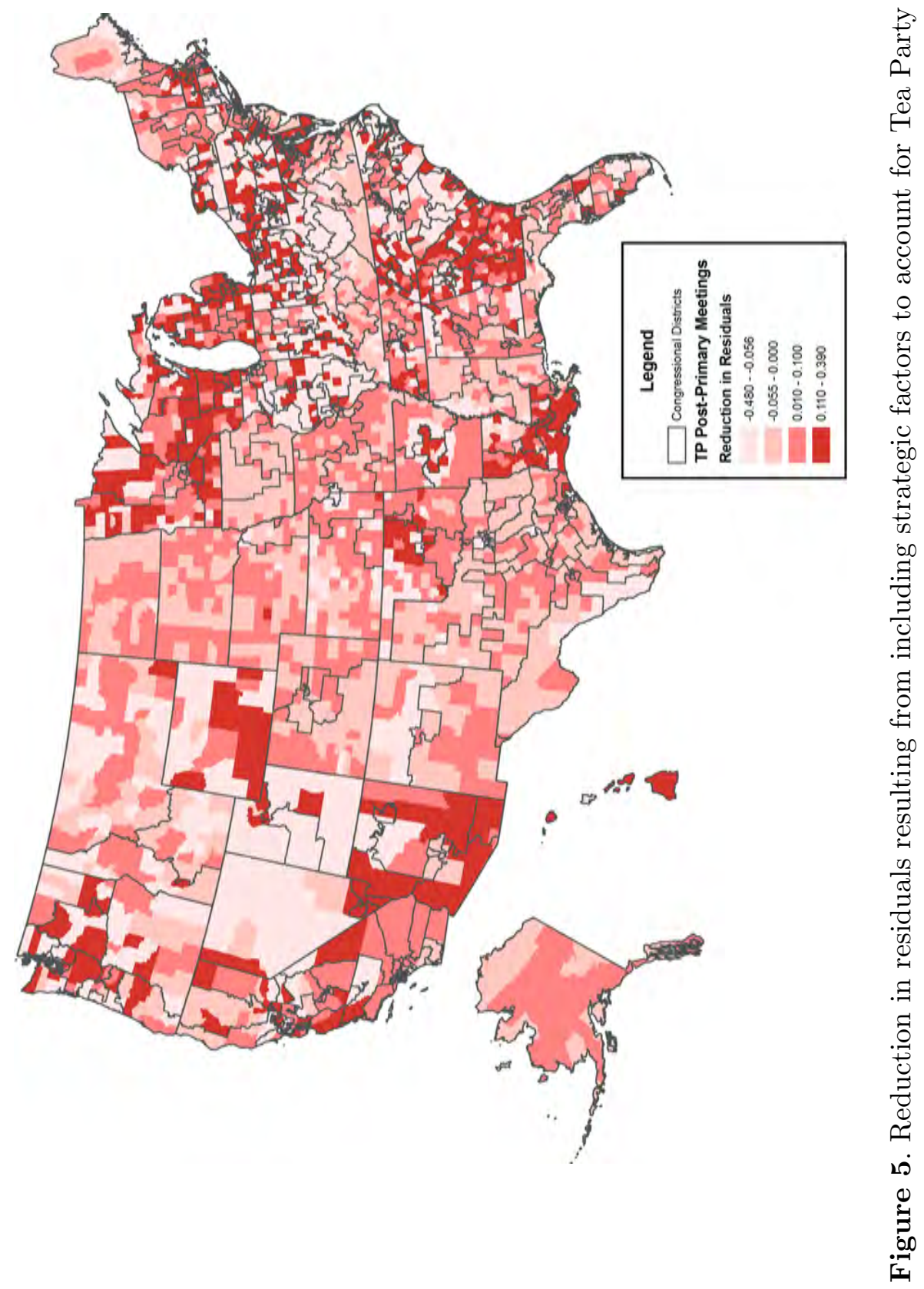


a strategic calculation to target particularly vulnerable seats in the general election.

In spite of this evidence, however, Figure 5 also displays many locations where there was Tea Party activity without seat turnover. Conversely, there were seat gains that appeared to have nothing to do with instrumentally oriented Tea Party activity as captured by these models. Close inspection of Figure 5 indicates that it is unlikely that Republican seat gains in North Dakota, Colorado, Kansas, Texas, Virginia, and Mississippi, had much to do with Tea Party activity. In fact, well over half of the GOP seat gains could have occurred without local Tea Party enthusiasm.

\section{Discussion}

The Tea Party movement presents a conundrum for both the Washingtonbased punditry and the denizens of the Ivory Tower. Liberal and progressive skeptics dismissed the movement as inauthentic and "astro-turfed." Scholars assumed the movement, like most other social movements, relied on elite activists who bear the costs of organizing in order to gain specific benefits. But while we are convinced that elites of some stripe were critical in helping to organize events, it is very difficult to see the hand of traditional, political elites in the Tea Party patterns. Instead, this look at Tea Party geography demonstrates that activity is highly correlated with expressive factors. First and foremost, it is expressive of economic restlessness, especially in areas where home foreclosures were running high from 2008 onwards. This helps to explain the especially high rates of Tea Party activism in locations such as Florida, California, Nevada and Arizona. Tea Party acolytes were also expressive of the core principles of the anti-spending, libertarian philosophy that animated so much of the angry reaction to the Bush Administration's Troubled Asset Relief Program (TARP) late in 2008, President Obama's economic stimulus package, the health care reform package, and the proposal to assist troubled homeowners. Interestingly, Tea Party activity does not seem to coincide with immigration concerns, at least as measured by the concentration of localized immigrant populations. Collectively, the energy of this activism organized and mobilized more voters across the country in a wide variety of locations, including many GOP leaners and weak identifiers, but in many cases the beneficiaries of this heightened mobilization would have won their elections anyway. Once again, the point is not that elites 
were not involved nor is it that they were failed strategists. Rather, it is that the geographic patterns of Tea Party activities do not reveal much evidence of electorally strategic direction in 2010 .

When activism contained a kernel of the electorally strategic in the early months of the year, it was often related to challenging incumbent and mainstream Republicans in primaries, and less obviously inclined toward longterm scenarios of governing. This led to clear-cut general election defeats in place of easy victories in Nevada and Delaware, and perhaps also in Colorado. But in other locations, Tea Party activity was sufficiently wellcoordinated to challenge and defeat prominent Democrats. Granted, in some locations Tea Party involvement did not help much over and above what would have occurred anyway, but at least it did not hurt. And in election contests across the Industrial Midwest, there appears to be good evidence that it was of benefit to the Republican nominees.

One of the most vexing challenges in campaign management as November approaches is that energy and enthusiasm for a candidate occurs in locations where it is least needed - among strong supporters, and in places where robust support can be taken for granted. This was no less true of Tea Party activism in 2010 than it is for many other kinds of grassroots activity aligned with parties and candidates. Feverish Tea Party activism was commonly found in areas where it was of little electoral benefit, e.g., in the districts of safe incumbents such as Cathy McMorris Rogers in Eastern Washington, Darrell Issa in Southern California, or Jack Kingston in Southern Georgia. The challenge as the general election approached was to heighten and otherwise redirect this activity to the locations where it could have the greatest mobilizing impact. Fortunately for Democrats, this happened on a very uneven and patchy basis with only sporadic guidance from Washingtonbased operatives. In the end, the best thing about the Tea Party as far as the Democratic Party is concerned is that through the 2010 election, it was a disorderly grassroots movement, with few of the markings of leadership and sophistication that would have led to more impressive gains in the 2010 midterms.

We conclude by noting that the collective action dilemma continues to be a major theoretical issue for scholars of elections and voting behavior, and that empirical studies of social and political movements constitute one of the most promising ways to improve our understanding of how political quiescence is overcome. Our successes in this regard are admittedly modest - we cannot claim to have done anything more than measure the impact of several 
plausible stimuli on Tea Party activity. Still, we believe this is exactly the sort of empirical investigation necessary to create a body of work required for theory building. Furthermore, we believe that incorporating geographic analyses into the study of political phenomena will enhance our understanding of important micro-level processes associated with group development. Seen in this light, the Tea Party movement is not only fascinating in its own right, but also serves as a marker for our ability to describe and understand a range of political phenomena.

\section{References}

Aldrich, J. 1996. Why Parties? Chicago: University of Chicago Press.

Anselin, L. 1988. Spatial Econometrics: Methods and Models. Dordrecht: Kluwer Academic Publishers.

Anselin, L. and A. Bera. 1998. "Spatial Dependence in Linear Regression Models with an Introduction to Spatial Econometrics," In Handbook of Applied Economic Statistics, Ullah, A. and D. E. Giles, eds., New York, NY: Marcel Dekker, pp. 237-289.

Anselin, L. and A. Daniel Griffith. 1988. "Do Spatial Effects Really Matter in Regression Analysis?" Papers of the Regional Science Association 65: 11-34.

Anselin, L., A. Bera, R. Florax, and M. Yoon. 1996. "Simple Diagnostic Tests for Spatial Dependence." Regional Science and Urban Economics 26: 77-104.

Baron, J. 2001. "Confusion of Group-Interest and Self-Interest in Parochial Cooperation on Behalf of a Group." Journal of Conflict Resolution 45(3): 283-296.

Brennan, G. and J. M. Buchanan. 1984. "Voter Choice: Evaluating Political Alternatives." American Behavioral Scientist 28(4): 185-201.

Brennan, G. and A. Hamlin. 1998. "Expressive Voting and Electoral Equilibrium." Public Choice 95(1,2): 149-175.

Brennan, G. and L. Lomasky. 1985. "The Impartial Spectator Goes to Washington: Toward a Smithian Theory of Electoral Behavior." Economics and Philosophy 1(3): 189-211.

Brennan, G. and L. Lomasky. 1993. Democracy and Decision: The Pure Theory of Electoral Preference. New York: Cambridge University Press.

Busch, A. E. 2010. "The 2010 Midterm Elections: An Overview." The Forum 8(4): Article 2. Available at http://www.bepress.com/forum/vol8/iss4/art2.

Chen, L. J. and A. Reeves. 2011. "Turning Out the Base or Appealing out the Periphery? An Analysis of County-Level Candidate Appearances in the 2008 Presidential Campaign." American Politics Research 39(3): 534-556.

Cho, W. K. Tam and N. Baer. 2011. "Environmental Determinants of Racial Attitudes, Redux: The Critical Decisions Related to Operationalizing Context." American Politics Research 39(2): 414-436.

Courser, Z. 2010. "The Tea Party at the Election." The Forum 8(4): Article 5. Available at http://www.bepress.com/forum/vol8/iss4/art5.

Ebeid, M. and J. Rodden. 2006. "Economic Geography and Economic Voting: Evidence from the U.S. States." British Journal of Political Science 36(3): 527-547.

Engelen, B. 2006. "Solving the Paradox: The Expressive Rationality of the Decision to Vote." Rationality and Society 18(4): 419-441.

Finkel, S. E., E. N. Muller and K.-D. Opp. 1989. "Personal Influence, Collective Rationality and Mass Political Action." American Political Science Review 83(3): 885-903.

Getis, A. and J. K. Ord. 1992. "The Analysis of Spatial Association by Use of Distance Statistics." Geographical Analysis 24(2): 189-206. 
Hirsh, M. 2010. "What Sparked the Tea Party?" National Journal. November 13. Available at: http://nationaljournal.com/member/magazine/how-bush-helped-sparkthe-tea-party-20101111.

Holbrook, T. M. and S. D. McClurg. 2005. "The Mobilization of Core Supporters: Campaigns, Turnout and Electoral Composition in United States Presidential Elections." American Journal of Political Science 49(4): 689-703.

Karpowitz, C. F., J. Quin Monson, K. D. Patterson, and J. C. Pope. 2011. "Tea Time in America? The Impact of the Tea Party Movement on the 2010 Midterm Elections." P.S.: Political Science and Politics 44(2): 303-309.

Kirby, D. and D. Boaz. 2010. "The Libertarian Vote in the Age of Obama." Cato Institute. Policy Analysis Paper No. 658. January 21. Available at http://www.cato. org/pubs/pas/pa658.pdf.

Kyriacou, A. P. 2011. "Rational Irrationality and Group Size: The Effect of Biased Beliefs on Individual Contributions Toward Collective Goods." American Journal of Economics and Sociology 70(1): 109-130.

LeSage, J. and R. Kelley Pace. 2009. Introduction to Spatial Econometrics. Boca Raton, FL: CRC Press.

Lo, C. Y. H. 1982. "Countermovements and Conservative Movements in the Contemporary U.S." Annual Review of Sociology 8: 107-134.

McGrath, B. 2010. "The Movement: The Rise of Tea Party Activism." The New Yorker. February 1. Available at http://www.newyorker.com/reporting/2010/02/01/ 100201fa_fact_mcgrath.

Minkoff, D. C. 1997. "Producing Social Capital: National Social Movements and Civil Society." American Behavioral Scientist 40(5): 606-619.

Openshaw, S. and P. J. Taylor. 1979. "A Million or So Correlation Coefficients: Three Experiments on the Modifiable Areal Unit Problem." In Statistical Applications in the Spatial Sciences, Wrigley, N., ed., London, UK: Pion.

Opp, K.-D. 1986. "Soft Incentives and Collective Action: Participation in the Anti-Nuclear Movement." British Journal of Political Science 16(1): 87-112.

Schlozman, K. L. and S. Verba. 1979. Injury to Insult: Unemployment, Class, and Political Response. Cambridge: Harvard University Press.

Schuessler, A. A. 2000. "Expressive Voting." Rationality and Society 12(1): 87-119.

Shaw, D. R. 2006. The Race to 270: The Electoral College and the Campaign Strategies of 2000 and 2004. Chicago, IL: University of Chicago Press.

Shaw, D. R. 1999. "The Effect of TV Ads and Candidate Appearances on Statewide Presidential Votes, 1988-1996." American Political Science Review 93(2): 345-361.

Williamson, V., T. Skocpol, and J. Coggin. 2011. "The Tea Party and the Remaking of Republican Conservatism." Perspectives on Politics 9(1): 25-43.

Zernike, K. 2010. Boiling Mad: Inside Tea Party America. New York: Times Books. 